\title{
INOVASI PELAYANAN SI DUKUN 3 IN 1 DI RUMAH SAKIT UMUM DAERAH PASAR MINGGU JAKARTA SELATAN
}

\author{
Devia Andiani') dan Retnowati W. D. Tuti²) \\ 1)Universitas Muhammadiyah Jakarta, Tangerang Selatan \\ deviaandiani11@gmail.com \\ 2)Universitas Muhammadiyah Jakarta, Tangerang Selatan \\ retnowatiwdtuti@yahoo.com
}

\begin{abstract}
Abstrak
Tujuan penelitian ini adalah untuk menganalisis Inovasi pelayanan Si Dukun 3 In 1 di Rumah Sakit Umum Daerah Pasar Minggu Jakarta Selatan untuk ,mengetahui faktor pendukung dan penghambat dalam pelaksanaan sistem si dukun 3 in 1 di RSUD Pasar Minggu. Penelitian ini menggunakan 5 indikator dari teori Rogers, dan menggunakan metode penelitian Deskripstif dengan pendekatan Kualitatif. Pengumpulan data dilakukan dengan cara wawancara, observasi, dan dokumentasi. Analisis data menggunakan Model Analisis dari Miles dan Huberman. Hasil penelitian ini menunjukkan bahwa inovasi pelayanan Si Dukun 3 In 1 di Rumah Sakit Umum Daerah Pasar Minggu Jakarta Selatan di ukur melalui atribut Relative advantage (keuntungan relatife), dilihat dari kepuasan masyarakat yang telah merasakan pelayanan program Si Dukun 3 In 1. Sampai saat ini semua masih dalam penilaian positif dengan penanganan yang cepat tanggap dan ramah. hanya saja untuk masalah ditiadakannya pembuatan BPJS yang sangat disayangkan. Compability, Dalam kesesuaian inovasi si dukun 3 in 1 dianggap sudah sangat sesuai oleh masyarakat dengan apa yang diharapkan masyarakat selama ini, karna sekarang masyarakat lebih mudah dan praktis. Complexity, Dengan adanya respon yang baik dari pegawai Rumah Sakit dan sistem yang konsisten, maka pelayanan si dukun 3 in 1 berjalan dengan baik. Maka dari itu masyarakat tidak merasakan ada nya kesulitan maupun kendala. Triabilty, Dalam masa pengembangannya program Si Dukun 3 In 1 mencoba untuk uji langsung ke publik dan hasil yang di terima cukup memuaskan, itu bisa di lihat dari rasa puas yang dirsakan masyarakat yang telah mencoba pelayanan Si Dukun 3 In 1 di RSUD Pasar Minggu.
\end{abstract}

Kata Kunci: Inovasi, Pelayanan, Si dukun 3 in 1

\begin{abstract}
The purpose of this study was to analyze the service innovation of SI DUKUN 3 IN 1 at the Pasar Minggu General Hospital in South Jakarta to find out the supporting and inhibiting factors in the implementation of the 3 in 1 traditional healer system at Pasar Minggu Hospital. This study uses 5 indicators from Rogers' theory, and uses descriptive research methods with a qualitative approach. Data collection is done by interview, observation, and documentation. Data analysis using the Analysis Model from Miles and Huberman. The results of this study indicate that the service innovation of SI DUKUN 3 IN 1 at the Pasar Minggu General Hospital in South Jakarta was measured through the attributes of Relative advantage, seen from the satisfaction of the people who had felt the services of the 3 IN 1 DUKUN SUPPORT program. all are still in a positive assessment with responsive and friendly handling. it's just that for the problem the elimination of BPJS was eliminated which was very unfortunate. Compability, In conformity with the innovation of the shaman 3 in 1 it is considered to have been very suitable for the community with what was expected by the community so far, because now the community is easier and more practical. Complexity, With a good response from Hospital staff and a consistent system, the service of the 3 in 1 shaman goes well. So from that the community does not feel any difficulties or obstacles. Triabilty, During the development of the 3 IN 1 DUKUNUN program tried to test directly to the public and the results received were quite satisfactory, it could be seen from the satisfaction that the community had tried service for SI DUKUN 3 IN 1 at RSUD Pasar Minggu.
\end{abstract}

Keywords: Innovation, Service, Si dukun 3 in 1 


\section{PENDAHULUAN}

\section{Latar Belakang Masalah}

Hakikat penyelenggaraan pelayanan publik adalah memberikan pelayanan secara prima kepada masyarakat yang merupakan tugas dan kewajiban para aparatur Negara sebagai abdi masyarakat. Pelayanan publik menjadi ranah dimana Negara berinteraksi secara intensif dengan masyarakat. Masyarakat selalu menuntut pelayanan yang prima, namun secara empiris pelayanan publik yang terjadi selama ini belum sepenuhnya sesuai dengan harapan masyarakat. Realita beberapa birokrasi pelayanan publik di Indonesia masih ditandai dengan adanya berbagai pelanggaran terhadap landasan konstitusi, peraturan perundang-undangan, dan etika pemerintahan. Hal ini dilihat dari banyaknya pengaduan dan keluhan dari masyarakat, seperti prosedur yang berbelitbelit, tidak ada kepastian jangka waktu penyelesaian dan biaya, persyaratan yang tidak transparan dan petugas yang kurang responsif.

Pada umumnya kedudukan hukum seseorang dimulai pada saat ia dilahirkan dan akan berakhir pada saat ia meninggal. Sedangkan peristiwa kelahiran sampai dengan kematian seseorang, akan membawa akibat-akibat hukum yang sangat penting tidak saja untuk yang bersangkutan sendiri, akan tetapi juga bekas isteri atau bekas suami dan anak-anak mereka. Berdasarkan itu, maka sangatlah perlu seseorang itu memiliki dan memperoleh suatu tanda bukti diri dalam kedudukan hukumnya, supaya mudah mendapatkan kepastian tentang kejadian-kejadian tersebut.

Kelahiran merupakan peristiwa hukum yang memerlukan adanya suatu peraturan yang tegas, jelas dan tertulis sehingga tercipta kepastian hukum dalam masyarakat.

Oleh karena itu pemerintah mengeluarkan beberapa peraturan diantaranya adalah peraturan mengenai kelahiran. Setiap kelahiran wajib dilaporkan oleh penduduk kepada instansi pelaksana di tempat terjadinya peristiwa kelahiran paling lambat 60 (enam puluh) hari sejak kelahiran.

Kegagalan orangtua untuk mencatatkan anaknya dalam jangka waktu segera setelah kelahirannya, seharusnya justru mendorong Negara untuk lebih keras melakukan kegiatan proaktif pencatatan kelahiran dan bukannya menambah kesulitan dengan "menghukum" anak tersebut dengan sanksi dan denda untuk mendapatkan hak identitasnya, apapun kesalahan atau kelalaian dari orangtuanya.

Pencatatan kelahiran merupakan hal yang sangat penting bagi orang yang bersangkutan maupun bagi negara, karena dengan adanya pencatatan kelahiran yang teratur maka berbagai persoalan dapat diselesaikan, misalnya dapat diketahui pertambahan penduduk, hal ini akan membantu pemerintah dalam menetapkan kebijaksanaan yang berhubungan dengan masalah kependudukan.

Pencatatan kelahiran adalah cara untuk mengamankan hak anak lain, misalnya identifikasi anak sesudah berperang, anak ditelantarkan atau diculik, agar anak dapat mengetahui orang tuanya (khususnya jika lahir diluar nikah), sehingga mereka mendapat akses pada sarana atau prasarana dalam perlindungan negara dalam batas usia hukum (misalnya: pekerjaan, rekruitment $\mathrm{ABRI}$, dalam sistem peradilan anak) serta mengurangi atau kemungkinan penjualan bayi.

Mahkamah Konstitusi menegaskan, akta kelahiran adalah hal yang sangat penting bagi warga negara. Dengan akta kelahiran, seseorang mendapat pengakuan, jaminan, perlindungan, dan kepastian hukum karena dirinya telah tercatat oleh negara. Akta itu pula yang mengikat hak dan kewajiban hukum, status pribadi, dan status kewarganegaraan.

"Proses untuk memperoleh akta kelahiran yang membutuhkan prosedur administrasi dan waktu yang panjang serta biaya yang lebih banyak dapat merugikan penduduk. Padahal, akta kelahiran merupakan dokumen penting yang diperlukan dalam berbagai keperluan," demikian penggalan pertimbangan MK dalam putusan No. 18/PUU-XI/2013.

Data warga yang belum memiliki akta kelahiran, pada masa sebelum dan sesudah UU diubah, memang menunjukkan penurunan. Secara nasional, pada 2012 warga tanpa akta kelahiran mencapai 27,4 persen. Angka ini membaik pada 2016, menjadi 18 persen".

Wilayah perdesaan menjadi wilayah dengan penduduk paling banyak tak memiliki 
akta kelahiran, sebanyak 23,76 persen. Sedangkan penduduk di wilayah perkotaan yang belum tercatat dan punya akta kelahiran, mencapai 12,31 persen. Berikut gambaran presentase alasan penduduk tidak memiliki akta lahir:

Gambar 1.1 Presentase Alasan Utama tidak memiliki akta kelahiran

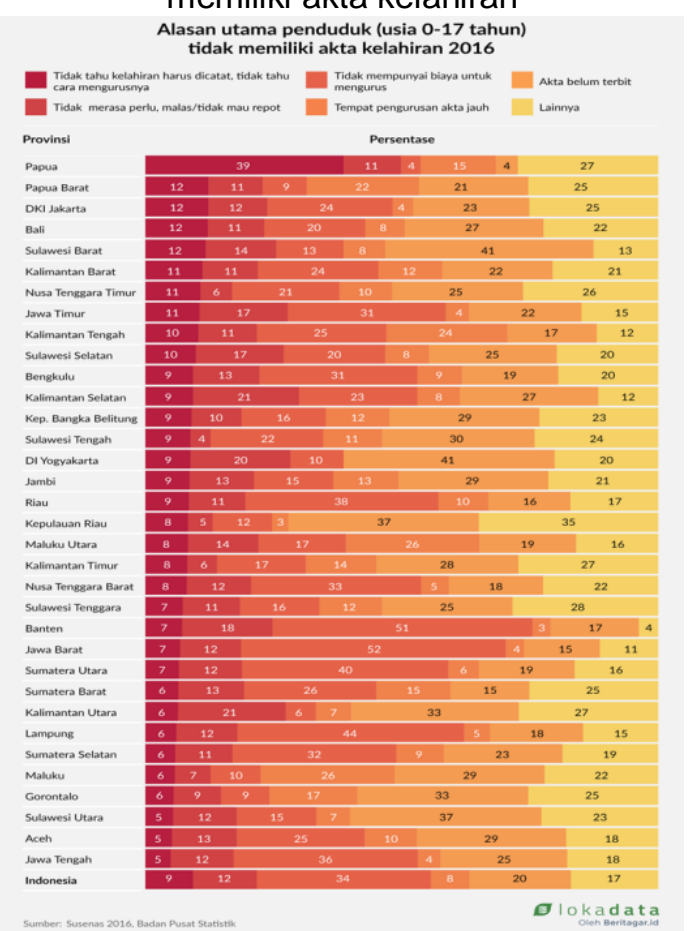

Sumber: detik.com tahun 2016

Berdasarkan data diatas maka dapat diketahui bahwa alasan utama penduduk usia 0-17 tahun tidak memiliki akta kelahiran pada tahun 2016 di Indonesia adalah 9\% karena tidak tahu kelahiran harus dicatat, tidak tahu cara mengurusnya. 12\% tidak merasa perlu, malas/tidak mau repot. 34\% tidak mempunyai biaya untuk mengurus. $8 \%$ tempat pengurusan jauh. $20 \%$ akta belum terbit. Dan $17 \%$ lainnya. Sedangkan untuk daerah DKI Jakarta dapat diketahui 12\% karena tidak tahu kelahiran harus dicatat, tidak tahu cara mengurusnya. 12\% tidak merasa perlu, malas/tidak mau repot. $24 \%$ tidak mempunyai biaya untuk mengurus. 4\% tempat pengurusan jauh. 23\% akta belum terbit. Dan 25\% lainnya. Hal inilah yang memperhambat setiap bayi yang dilahirkan tidak terpenuhi haknya.

Maka dari itu pada tahun 2013, Pemerintah Republik Indonesia melalui Kementerian Pendayagunaan Aparatur Negara dan Reformasi Birokrasi mencanangkan gerakan One Agency One Innovation, Pemerintah Republik Indonesia menetapkan tahun 2014 sebagai tahun inovasi pelayanan publik.

Dengan adanya gerakan One Agency One Innovation pemerintah Kota DKI Jakarta membuat suatu inovasi. Membuat komitmen bersama dengan BPJS Kesehatan DIVRE IV untuk mewujudkan tertib adminduk sekaligus meningkatkan kesejahteraan penduduk dan kesehatan bayi diwujudkan dengan "Pelayanan Si Dukun 3 In 1 di RSUD," yakni sistem pelayanan terintegrasi dokumen kependudukan dengan persalinan dan kepesertaan BPJS. Dan untuk proses pelayanan si dukun 3in 1 sebagai berikut: data/biodata bayi yang diinput di Loket Pelayanan Persalinan RSUD melalui webdesk akan langsung terkirim ke database kependudukan untuk proses akte lahir, KK (kartu keluarga), dan KIA (kartu identitas anak). Selanjutnya akte lahir, KK (kartu keluarga) dan KIA (kartu identitas anak) yang diterbitkan oleh Disdukcapil melalui webdesk/webservice. Dapat di ambil dengan waktu pembuatan maksimal 3 hari. Kini penduduk yang mengalami persalinan di RSUD cukup dengan membawa persyaratan KK, copy KTP suami-isteri, akta perkawinan dan copy KTP 2 orang saksi pada saat pendaftaran persalinan di RSUD, akan mendapatkan pelayanan terintegrasi, yakni pelayanan persalinan Surat Keterangan Kelahiran dari RSUD, KK, Akta Kelahiran, dan KIA (Sudin Dukcapil). Dengan Pelayanan Si Dukun 3 In 1 ini akan memudahkan dan mempercepat masyarakat mencatatkan kelahiran anak, mendapatkan akte lahir, KK (kartu keluarga) dan KIA (kartu identitas anak), sehingga kesejahteraan bayi/keluarga meningkat. Selain itu, cakupan akta kelahiran dan akurasi data penduduk juga meningkat, karena data kelahiran bayi di RSUD akan langsung terkirim secara online ke dalam database kependudukan.

Atas upaya yang dilakukan oleh pemerintah Kota DKI Jakarta pada tahun 2017 mendapatkan TOP 40 Inovasi Pelayanan Publik Nasional dalam penyelenggaraan program si dukun 3 in 1 .

Maka diangakat topik permasalahan ini kedalam suatu penelitian. "Inovasi Pelayanan Si Dukun 3 in 1 di RSUD Pasar Minggu Jakarta Selatan". 


\section{Identifikasi Masalah}

Permasalahan penelitian di ajukan ini dapat di identifikasi permasalahannya sebagai berikut.

1. Bagaimanakah Inovasi Pelayanan $\mathrm{Si}$ Dukun 3 in 1 di RSUD Pasar Minggu Jakarta Selatan.

2. Bagaimanakah kepemimpinan di RSUD Pasar Minggu Jakarta Selatan.

3. Apa saja faktor pendorong dan penghambat dalam program pelayanan Si Dukun 3 in 1 di RSUD Pasar Minggu Jakarta Selatan.

\section{Pembatasan Masalah}

Berdasarkan identifikasi masalah yang ditemukan maka permasalahan dibatasi pada Bagaimanakah inovasi pelayanan $\mathrm{Si}$ Dukun 3 in 1 di RSUD Pasar Minggu Jakarta Selatan.

\section{Rumusan Masalah}

Berdasarkan latar belakang masalah, identifikasi masalah dan pembatasan masalah yang telah diuraikan di atas, maka rumusan masalah penelitian ini adalah:

1. Bagaimanakah Inovasi Pelayanan Si Dukun 3 in 1 di RSUD Pasar Minggu Jakarta Selatan?

2. Apa saja yang faktor pendorong dan penghambat di dalam pelayanan $\mathrm{Si}$ Dukun 3 in 1 di RSUD Pasar Minggu Jakarta Selatan?

\section{Tujuan Penelitian}

Berdasarkan pada pokok permasalahan di atas maka tujuan dari penulisan penelitian ini adalah:

1. Untuk menganalisis Inovasi Pelayanan Si Dukun 3 In 1 di RSUD Pasar Minggu Jakarta Selatan.

2. Untuk mengetahui apa saja yang menjadi faktor pendorong dan penghambat dalam pelayanan Si Dukun 3 in 1 di RSUD Pasar Minggu Jakarta Selatan.

\section{Manfaat Penelitian}

\section{Secara Teoritis}

Penelitian ini diharapkan dapat memberikan informasi, meningkatkan pengetahuan dan wawasan bagi perkembangan tentang inovasi pelayanan publik serta teori Rogers.

2. Secara Praktis

Penelitian ini diharapkan dapat dijadikan motivasi dan semangat dalam memberikan pelayanan Si Dukun 3 in 1 yang lebih baik lagi kepada masyarakat di RSUD Pasar Minggu Jakarta Selatan.

Penelitian ini di harapkan dapat memberikan informasi sebagai masukan untuk mengoptimalkan pelayanan publik dalam pelayanan Si Dukun 3 in 1 pada RSUD Pasar Minggu Jakarta Selatan.

\section{TINJAUAN PUSTAKA}

\section{Penelitian Terdahulu}

Penelitian terdahulu ini menjadi acuan dalam penelitian yang sedang dilakukan sebagai bahan untuk tinjauan pustaka serta dapat memperkaya teori yang digunakan. Berdasarkan penelusuran dari beberapa studi terdahulu, terdapat lima karya ilmiah yang digunakan untuk penelitian terdahulu. Berikut ini lima karya ilmiah yang digunakan sebagai bahan tambahan untuk penelitian ini:

Penelitian Pertama, Inovasi Jaminan Kesehatan Semesta Dalam Usaha Meningkatkan Kualitas Pelayanan Kesehatan Bagi Peserta Jaminan Penyangga Di Daerah Istimewa Yogyakarta (Jurnal Natapraja Vol 5, No 1 (2017). Penulis: Nova Lestari Penelitian ini menggunakan metode deskriptif kualitatif. Teknik pengumpulan data dilakukan dengan cara wawancara dan observasi. Pemeriksaan keabsahan data dilakukan melalui metode triangulasi sumber. Proses analisis data mencakup reduksi data, penyajian data, dan penarikan kesimpulan. Hasil penelitian menunjukkan bahwa unsur SDM, proses, pembiayaan, lokasi, respon terhadap saran perbaikan inovasi, hukum, dan sosial sudah mendukung pelaksanaan inovasi Jaminan Kesehatan Semesta terhadap golongan penyangga dan bayi baru lahir. Namun, masih terdapat beberapa kekurangan yang perlu diperbaiki jika dilihat dari unsur sosialisasi, budaya dan teknologi. Sementara itu, unsur hasil menunjukkan bahwa sebanyak $45 \%$ dari total jumlah surat eligibilitas peserta (SEP) yang dikeluarkan oleh Bapel Jamkesos adalah untuk golongan penyangga tanpa KTP dan bayi baru lahir. 
Hal tersebut mengindikasikan bahwa visi Jamkesta dan amanah dari Gubernur DIY sudah tercapai.

Penelitian kedua, Inovasi Layanan Anak Lahir Membawa Akta Kelahiran Dan Kartu Keluarga (Alamak) Di Kabupaten Sidoarjo Tahun 2017 (Jurnal Publika Vol 6, No 4 (2018) penulis: Fajar Ningtias. Jenis penelitian yang digunakan yaitu deskriptif dengan pendekatan kualitatif. Teknik analisis data terdiri Dari observasi, wawancara dan dokumentasi. Teknik analisis data dilakukan dengan pengumpulan data, reduksi data, penyajian data dan penarikan kesimpulan. Hasil penelitian inovasi Anak Lahir Membawa Akta Kelahiran dan Kartu Keluarga (ALAMAK).

1. Leadership, pemimpin Dispendukcapil memiliki komitmen yang tinggi terhadap pekerjaan, bisa bekerja dalam tim serta mempunyai sikap ramah, dan disiplin.

2. Management/Organization, dilakukan mulai dari proses perencanaan dan penetapan strategi yang digunakan dalam layanan inovasi ALAMAK yaitu bekerjasama dengan RSUD Kabupaten Sidoarjo.

3. Risk Management, Dispendukcapil memiliki solusi untuk mengatasi dan mencegah risko yang bisa muncul dalam inovasi ALAMAK yaitu terkait kesalahan data dan teknis.

4. Human Capital, Pegawai DispendukCapil mengemban tugas dengan penuh tanggungjawab, serta dilakukan Bimbingan Teknis (BIMTEK) terkait proses pembuatan Akta Kelahiran dan Kartu Keluarga.

5. Technology, DispendukCapil menggunakan teknologi berupa web Sistem Informasi Administrasi Kependudukan (SIAK) dan web DispendukCapil Kabupaten Sidoarjo. Dapat disimpulkan bahwa inovasi layanan ALAMAK di Kabupaten Sidoarjo sudah berjalan dengan baik. Saran dari peneliti adalah menambahkan jumlah pegawai agar dalam proses pembuatan dokumen tidak telat dalam menyerahkannya, menyediakan aplikasi online yang terhubung dengan pihak RSUD, serta memaksimalkan sosialisasi.
Penelitian ketiga, Inovasi Sistem Administrasi Kependudukan Elektronik Lahir Dan Mati Pada Aplikasi E-Lampid (Studi Kasus Di Kecamatan Tambaksari Kota Surabaya Tahun 2017) (Jurnal Mahasiswa Ilmu Pemerintahan Vol 3, No 2 (2018) Penulis: Chikita Yuniar, Andi Setiawan, Irma Fitriana Ulfah. Metode penelitian yang digunakan adalah metode penelitian kualitatif dengan memaparkan secara deskriptif analisa. Kajian ini menganalisis inovasi E-LAMPID dengan menggunakan teori tahapan inovasi Bruno Dente dan Paola Coletti yang terdiri dari 4 tahapan. Pertama, inovasi agenda. Perencanaan awal lahirnya inovasi E-LAMPID hingga pada implementasi inovasi digunakan untuk memperbaiki kekurangan sistem yang sebelumnya. Kedua, inovasi proses. Program inovasi ELAMPID mampu memberikan beberapa solusi tentang permasalahan lama dan menciptakan hal baru. Ketiga, produk inovasi. Produk inovasi yang dihasilkan mampu membentuk kreasi baru yang dapat memberikan respon positif dari masyarakat. Keempat, komunikasi. Kemampuan untuk meningkatkan komunikasi dari dalam maupun dari luar dengan mempertahankan program inovasi dan mengkampanyekan.

Penelitian keempat, Inovasi Pelayanan Publik Dikecamatan Sungai Kunjangkota Samarinda (eJournal IImu Pemerintahan, 3 (3) 2015: 1472-1486) Dayang Erawati Djamrut Tahun 2015 Jenis penelitian ini menggunakan metode penelitian kualitatif. Hasil penelitian menunjukkan bahwa inovasi pelayanan publik di kecamatan sungai kunjang kota samarinda mempermudah masyarakat dalam mendapatkan pelayanan, mempercepat pelayanan dan memberikan akses informasi untuk memperlancar proses pelayanan untuk masyarakat sekitar.

Penelitian kelima, Inovasi Pelayanan Salam 20 Menit Pembuatan Akta Kelahiran Dan Kematian Di Dinas Kependudukan Dan Pencatatan Sipil Kabupaten Ponorogo (Jurnal Publika Vol 6, No 2 (2018) Toyibatur Rosidah Jenis penelitian yang digunakan adalah deskriptif dengan pendekatan kualitatif. Hasil penelitian ini menunjukkan bahwa pelayanan salam 20 menit pembuatan akta kelahiran dan kematian (5 hari) masih terdapat permasalahan dan belum sempurna yaitu 
berupa peralatan-peralatan yang belum memadai.

\section{Pelayanan Publik}

Pelayanan menurut Moenir (2010: 26) pelayanan adalah kegiatan yang dilakukan oleh seseorang atau sekelompok orang dengan landasan faktor materi melalui sistem, prosedur dan metode tertentu dalam rangka usaha memenuhi kepentingan orang lain sesuai dengan haknya. Pelayanan hakikatnya adalah serangkaian kegiatan, karena itu pelayanan merupakan sebuah proses. Sebagai proses, pelayanan berlangsung secara rutin dan berkesinambungan, meliputi seluruh kehidupan orang dalam masyarakat.

Pelayanan pada hakikatnya adalah serangkaian kegiatan, karena itu proses pelayanan berlangsung secara rutin dan berkesinambungan, meliputi seluruh kehidupan organisasi dalam masyarakat. Proses yang dimaksudkan dilakukan sehubungan dengan saling memenuhi kebutuhan antara penerima dan pemberi pelayanan.

\section{Inovasi}

Inovasi secara umum dipahami dalam konteks perubahan perilaku. Inovasi biasanya erat kaitannya dengan lingkungan yang berkarakteristik dinamis dan berkembang. Pengertian inovasi sendiri sangat beragam dan dari banyak perspektif. Menurut Rogers (Dalam Suwarno, 2008:9) mengatakan An innovation is an idea, practice, or object that is perceived as a new individual or other unit of adapter, yang artinya bahwa Rogers memaknai arti inovasi sebagai sebuah ide, praktek, atau objek yang dianggap benar-benar baru atau adaptasi dari hal lainnya. Lalu menurut Damanpour (Dalam Suwarno, 2008:9) sebuah inovasi dapat berupa produk atau jasa yang baru, teknologi proses produksi yang baru, sistem struktur dan administrasi baru atau rencana baru bagi anggota organisasi. Sedangkan menurut Albury (Dalam Suwarno, 2008:10) secara lebih sederhana mendefinisikan inovasi sebagai new ideas that work. Ini berarti bahwa inovasi selalu berhubungan erat dengan ideide baru yang bermanfaat.

\section{Atribut Inovasi}

Dengan merujuk pada pengertian-pengertian inovasi, sebuah inovasi tidak akan bisa berkembang dalam kondisi status quo. Inovasi mempunyai satu sifat mendasar yaitu sifat kebaruan. Sifat kebaruan ini merupakan ciri dasar inovasi dalam menggantikan pengetahuan, cara, objek, teknologi atau penemuan yang lama, yang sudah tidak efektif dalam menyelesaikan suatu masalah atau menjawab suatu kebutuhan tertentu. Walaupun tidak ada satu kesepahaman definisi mengenai inovasi, namun secara umum dapat disimpulkan bahwa inovasi mempunyai atribut. Atribut inovasi yang dimaksud menurut Rogers dalam Suwarno, (2008:16-18), antara lain sebagai berikut.

1. Relative advantage atau keuntungan relative

Sebuah inovasi harus mempunyai keunggulan dan nilai lebih dibandingkan dengan inovasi sebelumnya. Selalu ada sebuah nilai kebaruan yang melekat dalam inovasi yang menjadi ciri yang membedakannya dengan yang lain.

2. Compatibility atau kesesuaian Inovasi juga mempunyai sifat kompatibel atau kesesuaian dengan inovasi yang digantinya. Hal ini dimaksudkan agar inovasi yang lama tidak sertamerta dibuangbegitu saja, selain karena alasan faktor biaya yang tidak sedikit, namun juga inovasi yang lama menjadi bagian dari proses transisi keinovasi terbaru. Selain itu juga dapat memudahkan proses adaptasi dan proses pembelajaran terhadap inovasi itu secara lebih cepat.

3. Complexity atau kerumitan Dengan sifatnya yang baru, maka inovasi mempunyai tingkat kerumitan yang boleh jadi lebih tinggi dibandingkan dengan inovasi sebelumnya. Namun demikian, karena sebuah inovasi menawarkan cara yang lebih barudan lebih baik, maka tingkat kerumitan ini pada umumnya tidak menjadi masalah penting.

4. Triability atau kemungkinan diterapkan Inovasi hanya bisa diterima apabila telah teruji dan terbukti mempunyai keuntungan atau nilai lebih dibandingkan dengan inovasi yang lama. Sehingga sebuah produk inovasi harus melewati 
fase "uji publik", dimana setiap orang atau pihak mempunyai kesempatan untuk mengujii kualitas dari sebuah inovasi.

5. Observability atau kemudahan diamati Sebuah inovasi harus juga dapat diamati, dari segi bagaimana ia bekerja dan menghasilkan sesuatu yang lebih baik.

\section{METODE PENELITIAN}

\section{Tempat dan Waktu}

Penelitian dilakukan di rumah sakit yang sudah mengaplikasikan sistem Si Dukun 3 in 1 di Jakarta Selatan yaitu RSUD Pasar Minggu Jakarta Selatan, JI. TB Simatupang No.1, RT.1/RW.5, Ragunan, Pasar. Minggu, Kota Jakarta Selatan, Daerah Khusus lbukota Jakarta 12550. Pada bulan Agustus November 2018.

\section{Metode Penelitian}

Metode penelitian yang digunakan dalam penelitian ini adalah metode penelitian deskriptif dengan pendekatan kualitatif. Metode penelitian ini bertujuan untuk mengungkap masalah yang menjadi pokok penelitian dengan menggali fakta tentang Inovasi Pelayanan si Dukun 3 in 1 di Rumah Sakit Umum Daerah Pasar Minggu Jakarta Selatan. Penelitian ini menghasilkan data deskriptif yaitu berupa kata-kata tertulis maupun lisan dari objek penelitian, dan perilakunya yang dapat diamati. Data atau informasi yang dideskripsikan sesuai dengan kenyataan yang ada di lapangan dan disajikan dalam bentuk kata-kata atau kalimat kemudian ditarik suatu kesimpulan.

\section{Teknik Pengumpulan Data}

Untuk memperoleh data yang relevan dan lengkap dalam penelitian menggunakan teknik pengumpulan data sebagai berikut:

1. Wawancara

Wawancara digunakan untuk memperoleh data secara mendalam yang berkaitan dengan Inovasi Pelayanan Si Dukun 3 In 1 di RSUD Pasar Minggu Jakarta Selatan. Wawancara yang dilakukan dengan menggunakan pertanyaan-pertanyaan yang sudah disiapkan sebelumnya.dalam melaksanakan ini pertanyaan diajukan oleh peneliti kepada subjek penelitian dengan maksud memperoleh informasi yang akurat serta memperluas cakupan informasi yang didapat dari sumbersumber lain.

2. Observasi

Observasi dilakukan untuk menambah dan melengkapi data dari pengumpulan data dan melalui wawancara dan dokumentasi. Teknik ini dilakukandengan melihat atau mengamati secara langsung Inovasi Pelayanan Si Dukun 3 In 1 di RSUD Pasar Minggu Jakarta Selatan.

3. Dokumentasi

Dokumentasi ini digunakan untuk mengumpulkan data berupa sejarah berjalannya Inovasi Pelayanan Si Dukun 3 In 1 di RSUD Pasar Minggu Jakarta Selatan.

\section{Teknik Penarikan Informan}

Dalam penelitian ini penulis menggunakan teknik purposif sampling yaitu teknik penentuan sampel yang ditentukan atas dasar sampel yang dipilih dan ditentukan jumlahnya. Sebagaimana dalam penelitian kualitatif maka penulis menggunakan metode wawancara mendalam (in depth interview) dengan informan yang memiliki pengetahuan yang berkaitan dengan penelitian ini.wawancara dilakukan dengan cara terbuka dimana informan mengetahui kehadiran penulis sebagai peneliti yang melakukan wawancara di lokasi penelitian, dan dalam melakukan wawancara dengan para informan penulis menggunakan alat rekam sebagai alat bantu.

Sumber data dalam penelitian ini terdiri dari 2 yaitu:

1. Sumber Data Primer

Adapun Informan yang dipilih yaitu 1 orang Staff Rekam Medik yang membuat surat keterangan lahir, 1 orang operator Disdukcapil yang bertugas di RSUD Pasar Minggu.

2. Sumber data Sekunder

Sumber data sekunder dalam penelitian ini yaitu Masyarakat pengguna pelayanan Si Dukun 3 In 1 di RSUD Pasar Minggu Jakarta Selatan. 


\section{Teknik Analisis Data dan Uji Keabsahan}

\section{Teknik Analisis Data}

Teknik analisa data pada penelitian ini mengacu pada konsep miles \& Huberman (1992) yang mengemukakkan bahwa teknik analisa data pada penelitian dengan metode kualitatif terdapat tiga tahap. Karena analisis data kualitatif merupakan proses atau upaya berlanjut, berulang dan terus menerus. Tiga tahap analisis menurut miles dan Huberman yaitu:

1. Reduksi data (Data Reduction)

Reduksi data merupakan kegiatan merangkum, memilih hal-hal pokok, memfokuskan pada hal-hal yang penting, mencari tema dan polanya. Setelah data direduksi akan memberikan gambaran yang lebih jelas dan memudahkan peneliti untuk fokus mengumpulkan data yang akan di temukan.

2. Paparan Data (Data Display)

Setelah tahap reduksi maka tahap selanjutnya yaitu memaparkan data. Penyajian atau pemaparan data dilakukan untuk meningkatkan pemahaman kasus dan sebagai acuan mengambil tindakan berdasarkan pemahaman dan analisis sajian data. Paparan data disajiakan dalam bentuk uraian yang didukung dengan matriks jaringan kerja.

3. Penarikan Kesimpulan dan Verifikasi (Conclusion Drawing/Verifying)

Tahap selanjutnya yaitu Penarikan data, merupakan hasil penelitian yang menjawab fokus penelitian berdasarkan hasil analisis data. Kesimpulan disajikan dalam bentuk deskriptif objek penelitian dengan berpedoman pada kajian penelitian. Kegiatan ini merupakan kegiatan akhir dari analisis data dimana tahap analisis data mulai dari reduksi, paparan dan penarikan kesimpulan merupakan proses siklus dan interactif.

\section{Uji Keabsahan Data}

Uji keabsahan data dalam penelitian ini dengan menggunakan triangulasi yaitu untuk mendapatkan data dari sumber yang berbeda-beda dengan teknik yang sama. Langkah- langkah yang digunakan adalah:
1. Membandigkan data hasil pengamatan dengan hasil wawancara.

2. Membandingkan apa yang dikatakan orang di depan umum dengan apa yang dikatakan sepanjang waktu.

3. Membandingkan apa yang dikatakan orang-orang tentang situasi penelitian dengan apa yang dikatakan sepanjang waktu.

4. Membandingkan keadaan dan perspektif seseorang dengan berbagai karakter dan pandangan orang lain.

5. Membandingkan hasil wawancara dengan isi suatu dokumen yang berkaitan.

\section{HASIL DAN PEMBAHASAN}

\section{Pembahasan dan Hasil Penelitian}

Pembahasan penelitian merupakan pemaparan hasil penelitian yang didapatkan dengan melakukan wawancara dengan 8 (delapan) informan penelitian yang dianggap dapat mewakili dan memberikan data terhadap Inovasi Si Dukun 3 In 1 di RSUD Pasar Minggu.

Data yang didapatkan dari hasil penelitian di lapangan dianalisis dengan menggunakan konsep teori dari Rogers dalam Suwarno, (2008:16-18), yaitu : Relative Advantage (keuntungan relatif), Compability (kesesuaian), Complexity (kerumitan), Triability (kemungkinan diterapkan), Observability (kemudahan diamati).

Berikut adalah analisis penelitian mengenai Inovasi Si Dukun 3 In 1 di RSUD Pasar Minggu.

\section{Relative Advantage (keuntungan relatif)}

Sebuah inovasi harus mempunyai keunggulan dan nilai lebih dibandingkan dengan inovasi sebelumnya. Selalu ada sebuah nilai kebaruan yang melekat dalam inovasi yang menjadi ciri yang membedakannya dengan yang lain. memberikan kemudahan akses pelayanan masyarakat, dimana selama ini dalam pembuatan akte kelahiran, KK (kartu keluarga) dan KIA (kartu indentitas anak) masih sangat konvensional dalam memberikan pelayanannya.

Dengan adanya program inovasi Si Dukun 3 In 1 dapat memudahkan masyarakat dalam mendapatkan dukumen kelahiran bagi anak- 
anak mereka yang baru lahir. Prosesnya pun lebih mudah dan tidak berbelit belit dibandingkan dengan sebelumnya, dan inovasi ini juga gratis, jadi dapat dijangkau oleh masyarakat menengah kebawah, inovasi Si Dukun 3 In 1 memiliki nilai atau keunggulan yang sangat besar dibandingkan dengan proses sebelum adanya inovasi ini.

Berbeda dengan sebelumnya yang dimana Masyarakat harus hadir langsung ke lembaga pemerintahan yang bersangkutan (kelurahan, kecamatan, dan lembaga pemerintahan lainnya yang bersangkutan dengan untuk mengurus berbagai macam keperluan mereka, terkadang hasil yang mereka harapkan belum tentu selesai di hari tersebut dikarenakan minimnya informasi dan kesiapan dokumen pendukung yang mereka tidak ketahui.

Dalam hal pelayanan yang diberikan para staff maupun operator yang berada di RSUD Pasar Minggu juga sangat memuaskan, karena mereka siap memberikan bantuan dan penjelasan ataupun informasi apabila ada masyarakat yang belum mengerti tentang pelayanan Si Dukun 3 In 1 ini.

\section{Compabilty (kesesuaian)}

Inovasi juga sebaliknya mempunyai sifat kompatibel atau kesesuaian dengan inovasi yang sebelumnya. Hal ini dimaksudkan agar inovasi yang lama tidak serta merta dibuang begitu saja selain karena alasan faktor biaya yang sedikit namun juga inovasi yang lama menjadi bagian dari proses transisi ke inovasi baru.

inovasi Si Dukun 3 In 1 sangatlah sesuai dengan kebutuhan yang selama ini masyarakat harapkan, karena yang dulunya harus bolak-balik mengurus ini itu ke masingmasing instansi dan membuang banyak waktu ataupun biaya, sekarang tidak lagi karena hanya perlu memenuhi persyaratan dan mengisi formulir, maka masyarakat akan mendaptkan langsung 3 dokumen kelahiran bagi anak mereka.

Dan dalam hal kesamaan nilai manfaat dari inovasi Si Dukun 3 In 1 dengan sebelumnya adalah sama, tidak ada perbedaan nilai dan manfaat dalam inovasi Si Dukun 3 In 1 , karena bentuk dan nilai dari ketiga dokumen tersebut adalah sama dengan sebelumnya maupun dengan pembuatan manual tidak dengan program Si Dukun 3 In 1.

Untuk hal pembuatan akta lahir dan dokumen lain secara manual atau mandiri masih berlaku, , karena belum semua Rumah Sakit Di Jakarta belum mengaplikasikan Si Dukun 3 In 1 jadi apabila masyarakat melahirkan di Rumah Sakit selain di rumah sakit yang telah mengaplikasikan Si Dukun 3 In 1 harus mengurus Dokumen tersebut secara mandiri. Dan untuk masyarakat yang tidak memiliki KTP DKI Jakarta atau bukan berdomisili di Jakarta mereka pun harus mengurus Dokumen kelahiran secara mandiri, walaupun mereka melahirkan di Rumah Sakit Jakarta, karena inovasi ini hanya diperuntukkan bagi warga DKI Jakarta.

\section{Complexity (kerumitan)}

Tingkat kerumitan dari suatu inovasi untuk diadopsi, seberapa sulit memahami dan menggunakan inovasi. Semakin mudah suatu inovasi dimengerti dan dipahami oleh adopter, maka semakin cepat inovasi diadopsi.

Dalam pembuatan dokumen kelahiran dengan inovasi Si Dukun 3 In 1 tidak ada kesulitan yang dialami masyarakat karena semuanya dianggap mudah mulai dari pembuatan surat keterangan lahir, sampai pengurusan persyaratan yang harus dilengkapi, dan sampai dokumen nya semua jadi hanya memerlukan waktu 3 hari bahkan kurang, karena 3 hari itu adalah maksimal waktu pembuatan dokumennya, jadi saat ibu melahirkan pulang maka ia juga membawa dokumen kelahiran anaknya, tanpa harus mengurusnya lagi. Semua nya jelas terutama alur yang diberikan para staff maupun operator itu sendiri. Terutama dalam hal biaya yang sama sekali tidak ada, itu membuat masyarakat sangat terbantu karena sebelum adanya inovasi Si Dukun 3 In 1 mereka harus mengeluarkan biaya yang cukup besar dalam pembuatan dokumen kelahiran anaknya. Hanya saja terdapat kendala dari segi sumber daya manusia Disdukcapil yang berada di rumah sakit, yaitu hanya satu orang saja, operator dari Disdukcapil kepada rumah sakit tidak ada penggantinya, jadi apabila libur maka tidak dapat mengurus dokumen kelahiran, dan 
harus menunggu sampai petugas nya masuk kembali.

\section{Triability (kemungkinan dicoba)}

Merupakan tingkat apakah suatu inovasi dapat dicoba terlebih dahulu atau harus terikat untuk menggunakannya. Suatu inovasi dapat diuji cobakan pada keadaan sesungguhnya, inovasi pada umumnya lebih cepat diadopsi. Untuk lebih mempercepat proses adopsi, maka suatu inovasi harus mampu menunjukkan keunggulannya.

Inovasi dalam pelayanan publik merupakan penerapan suatu metode atau cara baru yang berbeda dengan metode yang sebelumnya bertujuan untuk memperbaiki metode yang lama sehingga dapat memberikan keuntungan bagi penggunanya. Inovasi dalam pelayanan publik akan diterima oleh masyarakat sebagai pengguna pelayanan apabila memiliki keuntungan yang telah terbukti melalui fase uji coba dimana setiap orang memiliki kesempatan yang sama untuk mencobanya. Inovasi pelayanan publik $\mathrm{Si}$ Dukun 3 In 1 telah melalui fase uji coba publik.

Fase uji publik memang ada, tetapi bersifat langsung kepada masyarakat saat peluncuran inovasi tersebut, bahwa saat uji coba dalam inovasi pelayanan Si Dukun 3 In 1 masyarakat merasa puas terhadap pelayanan yang diberikan itu lah yang menjadi fase uji publik secara keseluruhan di beberapa rumah sakit yang menjadi uji coba pelayanan $\mathrm{Si}$ Dukun 3 In 1 ini termasuk RSUD Pasar Minggu, dan nantinya akan diperluas lagi keberbagai rumah sakit lain di Jakarta. Jadi untuk saat ini masih bisa dikatakan bahwa pelayanan Si Dukun 3 In 1 masih menjadi fase uji publik untuk bisa di aplikasikan kepada rumah sakit di seluruh DKI Jakarta.

\section{Observability (kemudahan diamati)}

Tingkat bagaimana hasil penggunaan suatu inovasi dapat dilihat oleh orang lain. Semakin mudah seseorang melihat hasil suatu inovasi, semakin besar kemungkinan inovasi diadopsi oleh orang atau sekelompok orang.

Inovasi harus dapat diamati dengan mudah bagaimana inovasi tersebut bekerja dan bagaimana inovasi tersebut dapat menghasilkan sesuatu yang lebih baik atau menguntungkan dibandingkan dengan sebelumnya. Inovasi pelayanan Si Dukun 3 In 1 di RSUD Pasar Minggu dapat diamati dengan mudah bagaimana cara ia bekerja dan bagaimana inovasi dapat menghasilkan sesuatu yang lebih baik atau menguntungkan dibandingkan dengan sebelumnya.

Kemudahan akses menjadi suatu keberhasilan inovasi pelayanan Si Dukun 3 In 1 kepada masyarakat yang melahirkan dan akan mengurus dokumen kelahiran anaknya, karena masyarakat tidak lagi harus mengurus dokumen kelahiran dengan mendatangi instansi-instansi yang terkait, semua dapat diakses dalam satu pintu, masyarakat melahirkan disitu dan disitu pula mereka mengurus dan mendapatkan dokumen kelahiran anak mereka, kemudahan akses nya juga dapat dilihat mulai dari pengurusan surat keterangan lahir sampai mendapatkan ketiga dokumen tersebut, hal ini dapat dilihat tidak ada nya masyarakat yang mengeluh dan sangat mengapresiasi Si Dukun 3 In 1, tetapi sayangnya belum dapat diakses oleh seluruh masyarakat Jakarta yang dikarenakan belum merata nya pelayanan Si Dukun 3 In 1 di seluruh rumah sakit ataupun puskesmas di DKI Jakarta, masih hanya beberapa rumah sakit saja yang sudah ada pelayanan Si Dukun 3 In 1. Dengan tidak dikenakan biaya sepersen pun itu sudah memberikan kemudahan akses kepada masyarakat yang kurang mampu dalam mendapatkan dokumen kelahiran.

\section{Faktor Pendukung dan Penghambat Inovasi layanan Si Dukun 3 In 1 di RSUD Pasar Minggu}

Dalam penyelenggaraan Inovasi Si Dukun 3 In 1 terdapat banyak hal yang menjadi tolak ukur sejauh mana keberhasilan RSUD menerapkan Pelayanan inovasi dengan baik. Salah satunya dengan melihat faktor apa saja yang terjadi dalam Pelayanan inovasi Si Dukun 3 In 1 tersebut. Berikut adalah faktor pendukung dan faktor penghambat Inovasi Si Dukun 3 In 1 di RSUD Pasar Minggu : 


\section{Faktor Pendukung}

Faktor pendukung yang utama dalam inovasi Si Dukun 3 In 1 ini adalah;

1. Adanya anggaran daerah, dengan adanya anggaran daerah di setiap daerah maka mendorong pemerintah daerah untuk memberikan suatu program yang akan memberikan pelayanan kepada masyarakat.

2. Adanya penggunaan teknologi yang memadai, di tingkat teknologi yang semakin maju membuat pemerintah daerah ikut mengembangkan teknologi yang ada untuk memberikan pelayanan dan memudahkan masyarakat.

3. Adanya fasilitas yang memadai, adanya fasilitas seperti teknologi, peralatan maupun sumber daya manusia yang kompeten mendorong pemerintah membuat inovasi.

4. Adanya program One Agency One Innovation dengan adanya program One Agency One Innovation ini maka setiap daerah dituntut untuk membuat suatu inovasi.

\section{Faktor Penghambat}

Faktor Penghambat utama yang dihadapi dalam Inovasi Si Dukun 3 In 1 ini adalah:

1. Perlunya peningkatan sosialisasi yang lebih di perluas agar tidak hanya sekitar RSUD Pasar Minggu, jadi untuk warga daerah DKI Jakarta bisa tau untuk progam yang sedang di lakukan inovasi baru oleh pemerintah.

2. Tidak adanya pengganti dari operator Disdukcapil apabila sedang libur, akan pelayanan Si Dukun 3 In 1 dapat tetap berjalan.

\section{KESIMPULAN DAN SARAN}

\section{Kesimpulan}

Berdasarkan hasil pembahasan penelitian dapat ditarik sebuah kesimpulan bahwa Inovasi pelayanan Si Dukun 3 In 1 di RSUD Pasar Minggu dapat dijelaskan dengan teori dari Rogers dengan 5 indikator, yaitu:

1. Relative advantage (keuntungan relatife), dilihat dari kepuasan masyarakat yang telah merasakan pelayanan program Si Dukun 3 In 1. Sampai saat ini semua masih dalam penilaian positif dengan penanganan yang cepat tanggap dan ramah. Kemudahan yang dirasa oleh masyarakat dengan kemudahan persyaratan yang harus dilenkapi juga birokasi yang lebih mudah dibandingkan dengan prosedur pelayanan sebelumnya.hanya saja untuk masalah ditiadakannya pembuatan BPJS yang sangat disayangkan.

2. Compability, Dalam kesesuaian inovasi Si Dukun 3 In 1 dianggap sudah sangat sesuai oleh masyarakat dengan apa yang diharapkan masyarakat selama ini, karna sekarang masyarakat lebih mudah dalam membuat dokumen kelahiran anak-anak nya tanpa dipungut biaya sepersen pun, sedangkan untuk nilai dan manfaat inovasi Si Dukun 3 In 1 dengan pelayanan sebelumnya adalah sama, hanya berbeda dalam segi proses, ekonomis, dan praktis.

3. Complexity, Dengan adanya respon yang baik dari pegawai Rumah Sakit dan sistem yang konsisten, maka pelayanan Si Dukun 3 In 1 berjalan dengan baik. Maka dari itu masyarakat tidak merasakan ada nya kesulitan maupun kendala.

4. Triabilty, Dalam masa pengembangannya program Si Dukun 3 In 1 mencoba untuk uji langsung ke publik dan hasil yang di terima cukup memuaskan, itu bisa di lihat dari rasa puas yang dirsakan masyarakat yang telah mencoba pelayanan Si Dukun 3 In 1 di RSUD Pasar Minggu

5. Observability, Kemudahan akses yang diberikan pelayanan Si Dukun 3 In 1 membuat masyarakat jauh lebih mudah dalam mengurus dokumen, terutama respon pegawai yang siap untuk melayani masyarakat dengan baik.

\section{Saran}

Berdasarkan hasil pembahasan serta kesimpulan penelitian, dapat diketahui bahwa Inovasi Si Dukun 3 In 1 sudah berjalan dengan baik. Tetapi masih memerlukan perkembangan terkait program tersebut sebagai berikut.

1. Melakukan sosialisasi kepada masyarakat secara meluas tidak hanya memberikan sosialisasi apabila masyarakat yang bertanya dahulu. 
2. Lebih mudah apabila persyaratan bisa di akses secara online oleh masyarakat.

3. Menempatkan banner,standing banner tentang program $\mathrm{Si}$ Dukun 3 In 1 ditempat yang strategis, seperti pintu masuk,dan di kamar rawat inap ibu dan anak.

\section{DAFTAR PUSTAKA}

\section{Buku}

Davis, G. B. (1995). Sistem informasi manajemen. PT. Pustaka Binaman Pressindo.

Hardiyansyah. (2011). Kualitas pelayanan publik konsep, dimensi, indikator, dan implementasinya. Yogyakarta: Gava Media.

Hartono, J. (2000). Pengenalan komputer: Dasar ilmu komputer, pemograman, sistem informasi, dan intelegensi buatan. Yogyakarta: Edisi 3. Cet. Kedua. Andi.

Moekijat. (1991). Latihan dan pengembangan layanan pegawai. Bandung: Mandar Maju.

Moleong, L. J. 2001. Metode penelitian kualitatif. Bandung: PT. Remaja Rosdakarya.

Moenir, A. S. (2010). Manajemen pelayanan umum di Indonesia. Jakarta: Bumi Aksara.

Prianto, A. (2006). Menakar kualitas pelayanan publik. Malang: In-Trans

Rasyid, M. R. (1998). Desentralisasi dalam menunjang pembangunan daerah dalam pembangunan administrasi di Indonesia. Jakarta: Pustaka LP3ES.

Ratminto, \& Winarsih, A. S. (2006). Manajemen pelayanan. Yogyakarta: Pustaka Pelajar.

Rogers, E. M. (2003). Diffusion of innovations 5th edition. New York: The Free Press.

Setyaningrum, E. (2009). Innovative governance konsep dan aplikasi. Yogyakarta: Capiya Publishing.

Sinambela, L. (2014). Reformasi pelayanan publik. Surabaya: Media Aksara Globalindo.

Suwarno, Y. (2016). Inovasi di sektor publik. Jakarta: STIA LAN Press.

Widodo, J. 2001. Etika birokrasi dalam pelayanan publik. Malang: CV Citra.
Jurnal

Lestari, N. (2017). Inovasi jaminan kesehatan semesta dalam usaha meningkatkan kualitas pelayanan kesehatan bagi peserta jaminan penyangga di daerah istimewa. Yogyakarta; Jurnal Natapraja, 5(1).

Ningtias, F. (2018). Inovasi layanan anak lahir membawa akta kelahiran dan kartu keluarga (alamak) di Kabupaten Sidoarjo Tahun 2017. Jurnal Publika, 6(4).

Yuniar, C., Setiawan, A., \& Ulfah, I. F. (2018). Inovasi sistem administrasi kependudukan elektronik lahir dan mati pada aplikasi e-lampid (Studi kasus di Kecamatan Tambaksari Kota Surabaya Tahun 2017). Jurnal Mahasiswa IImu Pemerintahan, 3(2).

Djamrut, D. E. (2015). Inovasi pelayanan di Kecamatan Sungai Kunjang Kota Samarinda Tahun 2015. eJournal IImu Pemerintahan, 3(3), 1472-1486.

Rosidah, T. (2018). Inovasi pelayanan salam 20 menit pembuatan akta kelahiran dan kematian di Dinas Kependudukan dan Pencatatan Sipil Kabupaten Ponorogo Tahun 2018. Jurnal Publika, 6(2).

\section{Internet}

https://beritagar.id/artikel/berita/meski-gratis-

18-persen-penduduk-tanpa-akta-kelahiran

https://news.detik.com/berita/1735664/dinas-

kependudukan-beri-dispensasi-

pengurusan-akta-kelahiran

http://www.kpai.go.id/berita/akta-kelahiranhak-anak-yang-terabaikan

https://www.menpan.go.id/site/cerita-suksesrb/one-agency-one-innovation-dan-telaahkeilmuaannya

https://rb.bps.go.id/Clrbbps/assets/pdf/2017 \%20Buku_TOP_99_2017.pdf 